\title{
DIE INKOMSTEBELASTINGHANTERING VAN AANVANGSFRANCHISEFOOIE BETAALBAAR IN DIE SUID-AFRIKAANSE PETROLEUMBEDRYF
}

\author{
Leonard C Willemse* \\ Universiteit van Stellenbosch \\ Iwillemse@sun.ac.za
}

July 2011

\begin{abstract}
A wholesaler of petroleum products is prohibited in terms of section 12(2)(c) of Regulation 287 of the Petroleum Products Act, No. 120 of 1977, to own a retail licence for purposes other than that of training. As a result, petroleum companies make use of franchises to sell their products. The concept of a franchise is based on the principle that a franchisee obtains the franchise of an existing, often prosperous, business from a franchisor, and then operates the business under the banner of this franchise. The franchisee pays the franchisor franchise fees as consideration for certain items or privileges obtained. This article investigates the deductibility of franchise fees in terms of the current South African Income Tax Act, No. 58 of 1962 and includes an evaluation of Australian Income Tax Act sections that might offer deduction possibilities for franchise fees if applied within a South African context.
\end{abstract}

Keywords

Aanvangsfranchisefooi, franchise-ooreenkoms, franchisegewer, franchisehouer, herhalende franchisefooi, SAID, Inkomstebelastingwet, nr. 58 van 1962 (soos gewysig).

\footnotetext{
* Mr Leonard Christian Willemse is a lecturer in the accounting department at the University of Stellenbosch, South Africa.
} 


\section{INLEIDING}

Ingevolge afdeling 12(2)(c) van Regulasie 287 van die Wet op Petroleumprodukte, nr. 120 van 1977 , word ' $n$ groothandelaar van petroleumprodukte verbied om ' $n$ kleinhandelslisensie te besit anders as vir doeleindes van opleiding. Die gevolg hiervan is dat petroleummaatskappye van franchisehouers gebruik maak om hul vulstasies en geriefswinkels namens hulle te bedryf, aangesien die franchisehouers toegelaat word om kleinhandelslisensies vir besigheidsdoeleindes te besit.

Die konsep van ' $n$ franchise is daarop gegrond dat ' $n$ franchisehouer die franchise van ' $n$ bestaande, en dikwels welvarende, besigheid vanaf ' $n$ franchisegewer bekom en dan die besigheid namens die franchisegewer bedryf. Die franchisehouer betaal franchisefooie (normaalweg 'n eenmalige enkel-bedrag aanvangsfranchisefooie en/of deurlopende, herhalende franchisefooie) aan die franchise-gewer as teenprestasie vir ' $n$ verskeidenheid van items of vergunnings wat toegestaan is. Die vraag waarvoor franchisehouers gevolglik te staan kom, is of die onkoste wat vir inkomstebelastingdoeleindes aangegaan is, aftrekbaar is? Indien wel, hoe moet die aftrekking geëis word?

Alhoewel die onderwerp onder bespreking as relevant beskou word, is daar tot op hede min studies hieroor beskikbaar, met die gevolg dat hierdie artikel op huidige regspraak en wetgewing fokus en dus poog om hierdie gaping te oorbrug. Hiervoor word van toepaslike Suid-Afrikaanse en Australiese wetgewing, regspraak en menings van erkende belastingkenners van die beginsels van uitleg van wette wat in handboeke en vaktydskrifte voorkom, gebruik gemaak.

Die artikel stel ondersoek in na die inkomstebelastinghantering van aanvangsfranchisefooie wat deur die franchisehouers in die Suid-Afrikaanse petroleumbedryf betaalbaar is kragtens die huidige Suid-Afrikaanse Inkomstebelastingwet, nr. 58 van 1962 (Inkomstebelasting-wet). 'n Addisionele ondersoek na die inkomstebelastinghantering van franchisefooie in die ontwikkelde 'eerstewêreldland', Australië, word gedoen ten einde vas te stel of hierdie land van enige inkomstebelastingbeginsels of -praktyke gebruik maak wat binne 'n Suid-Afrikaanse konteks van nut kan wees om franchisefooie op ' $n$ korrekte en deursigtige wyse vir inkomstebelastingdoeleindes te hanteer.

Australië is lid van die Organisasie vir Ekonomiese Samewerking en Ontwikkeling (0ESO) wat toonaangewers is met betrekking tot die vestiging van eenvormige ekonomiese standaarde en toepassing van gesonde, deurdagte ekonomiese praktyk, onder andere op die gebiede van ekonomie, belasting en rekeningkunde (OECD Member Countries, [s.a.]). Suid-Afrikaanse inkomstebelasting-wetgewing toon verskeie ooreenkomste met dié van Australië vanweë die feit dat dit sy oorsprong aan die New South Wales Act van 1895 te danke het. Sedert die ingebruikneming daarvan in 1914 is daar verskeie wysigings aan en konsolidasies van die wet gemaak (Huxham \& Haupt, 2010). Australië word as 'n geskikte land beskou in die soeke na beginsels en praktyk wat ' $n$ struktuur kan skep waarbinne franchisefooie doeltreffend vir inkomstebelastingdoeleindes hanteer kan word.

\section{DIE WOORDOMSKRYWING EN WERKING VAN 'N FRANCHISE}

Volgens Angelopulo (2005) verskaf die Franchisevereniging van Suider-Afrika ' $n$ funksionele omskrywing van ' $n$ franchise: 
' $n$ Franchise is ' $n$ toekenning deur ' $n$ franchisegewer aan ' $n$ franchisehouer, wat laasgenoemde daarop geregtig maak om die volledige besigheidspakket te gebruik wat al die nodige elemente bevat om ' $n$ voorheen onopgeleide persoon in die franchisebesigheid te vestig, en om hom of haar in staat te stel om die besigheid op ' $n$ deurlopende basis, suksesvol en winsgewend te bedryf ingevolge die riglyne wat deur die franchise-ooreenkoms neergelê is (vertaling).

Die deurlopende betaling van die herhalende franchisefooi deur die franchisehouer word beskou as soortgelyk aan die betaling wat 'n persoon as huurder vir die regte wat hy as huurder bekom, maak, aangesien die fooi ' $n$ voortdurende vergoeding vir die gebruik van, onder andere, die franchisegewer se stelsels, handelsnaam en toerusting is (Huxham \& Haupt, 2010). Die gelykstelling van die herhalende franchisefooi met ' $n$ gewone huurbetaling word deur die uitspraak deur Davis J. in die belastinghofsaak ITC 176466 SATC 93 ondersteun. Die fooi kwalifiseer dus vir ' $\mathrm{n}$ aftrekking ingevolge die algemene aftrekkingsformule soos in artikels $11(a)$ en $23(\mathrm{~g})$ van die Inkomstebelastingwet vervat. ' $n$ Verdere bespreking van hierdie fooi val buite die omvang van hierdie artikel.

By nadere ondersoek blyk die inkomstebelastinghantering van die aanvangsfranchisefooi onduideliker as dié van die deurlopende herhalende fooi te wees. Die bewoording wat in die franchise-ooreenkoms gebruik word om hierdie eenmalige enkelbedrag te omskryf, is dikwels vaag en verg verdere interpretasie wat uit die aard van die saak die korrekte inkomstebelastinghantering daarvan bemoeilik. Ingevolge die meerderheid franchiseooreenkomste wat vir doeleindes van hierdie artikel bestudeer is, is die betaling van die eenmalige enkelbedragfranchisefooi gewoonlik vir die reg om as ' $n$ spesifieke franchise, hetsy $B P$, Engen of SASOL, ' $n$ besigheid te kan beoefen, of om byvoorbeeld as ' $n$ SASOL-franchise te kan optree en onder die SASOL-naam ' $n$ vulstasie en geriefswinkel te kan bedryf. Die aard van die fooi is dus van kardinale belang in die bepaling van die aftrekbaarheid daarvan vir inkomstebelastingdoeleindes.

\section{DIE AANVANGSFRANCHISEFOOI}

Volgens Blair en Lafontaine (2005) vereis die oorgrote meerderheid van franchisegewers dat hul franchisehouers ' $n$ eenmalige enkelbedragaanvangsfranchisefooi by die aanvang van die franchise-ooreenkoms moet betaal. Van die verskillende finansiële kontrakterme wat in ' $n$ franchise-ooreenkoms aanwesig is, is die aanvangsfranchisefooi ' $n$ term wat die meeste tussen franchisehouers oor verskeie industrieë heen en selfs binne dieselfde industrie verskil (Franchise fees, [s.a.]). Die bedrag kan onder andere dien as betaling vir die toegang tot die franchisegewer se netwerk, aanvanklike ondersteuning (Illetschko \& Parker, 2007), gebruik, of reg van gebruik, van handelsmerke, intellektuele eiendom en toegang tot kundigheid/kennis (Angelopulo, 2005; Illetschko \& Parker, 2007). Angelopulo (2005) noem verder dat die betaling van die fooi onder andere ook vir die gebruik, of reg van gebruik, van die franchisegewer se handelsgeheime, ontwerpe, kopieregte en patente kan wees. Dit is dus duidelik uit die uiteensettings van die fooi dat die aard van die betaling wesenlik ten opsigte waarvoor dit gemaak word, kan verskil. 


\section{TOEPASSING VAN DIE SUID-AFRIKAANSE INKOMSTEBELASTING- WETAFDELINGS}

$\mathrm{Na}$ ' $\mathrm{n}$ deeglike ondersoek van die Inkomstebelastingwet kon geen spesifieke aftrekkingsbepaling wat uits/uitlik verwys na die term franchisefooie en wat voorsiening maak vir die aftrekking van enigeen van die soorte franchisefooie opgespoor word nie. Daar is egter bepalings wat ' $n$ moontlike aftrekking kan bied, maar wat nie spesifiek na die term "franchisefooi" verwys nie, geïdentifiseer. Geen bepalings wat die aftrekbaarheid van franchisefooie eksplisiet verbied (binne die konteks van hierdie artikel) is geïdentifiseer nie. Alvorens die alternatiewe aftrekkingsmoontlikhede oorweeg word, word die aftrekbaarheid van die aanvangsfranchisefooi eers ingevolge die algemene aftrekkingsformule (soos vervat in artikels $11(\mathrm{a})$ en $23(\mathrm{~g})$ van die Wet) oorweeg.

\section{AFTREKBAARHEID VAN DIE AANVANGSFRANCHISEFOOI INGEVOLGE ARTIKELS 11(A) EN 23(G)}

Artikels 11 (a) en $23(\mathrm{~g})$ bepaal opsommenderwys dat ' $\mathrm{n}$ item slegs aftrekbaar sal wees indien dit: (1) ' $n$ onkoste of verlies is; (2) wat werklik aangegaan is; (3) geheel en al, of gedeeltelik, vir bedryfsdoeleindes; (4) gedurende die jaar van aanslag, (5) by die voortbrenging van inkomste; en (6) wat nie kapitaal van aard is nie.

Die vereiste dat die aanvangsfranchisefooi nie kapitaal van aard mag wees nie, het tot gevolg dat dit nie vir ' $n$ aftrekking ingevolge artikel 11 (a) kwalifiseer nie. In Suid-Afrika word daar hoofsaaklik van die sogenaamde "inkomste-genererende struktuur"-toets wat deur Watermeyer C) geformuleer is in die hofsaak New State Areas Ltd v CIR 1946 AD 610 (14 SATC 155) ('New State Areas'), gebruik gemaak om te bepaal of ' $n$ onkoste kapitaal van aard is of nie. Volgens Clegg en Stretch (2008) kom die toets daarop neer dat daar in wese vasgestel moet word of die onkoste wat aangegaan is as deel van die koste om die inkomste-genererende struktuur te bedryf (hierdie onkoste is inkomste van aard) beskou kan word of as deel van koste om die inkomstegenererende struktuur of kapasiteit daar te stel, te vestig, te verbeter of daartoe by te voeg (hierdie onkoste is kapitaal van aard). Toepassing van die toets toon dat die fooi aangegaan word met die doel om aan die franchisehouer die toegang, of reg, te gee om as ' $n$ spesifieke franchise besigheid te kan doen. Die betaling van die fooi plaas dus die belastingpligtige in die posisie om ' $n$ bedryf as ' $n$ franchisehouer te kan beoefen. Sonder hierdie fooi is geen besigheid of bedryf moontlik nie. Dit dui daarop dat die fooi die struktuur of bron waarmee die franchisehouer inkomste wil genereer, skep en tot stand bring. Die fooi word in effek "belê" om in die toekoms wins te lewer.

Uit bostaande blyk dit duidelik dat die aanvangsfranchisefooi ingevolge die 'inkomstegenererende struktuur'-toets as kapitaal van aard beskou behoort te word (die kapitale aard van die aanvangsfranchisefooi kan sekere kapitaalwinsbelastingimplikasies hê - die bespreking hiervan val egter buite die bestek van hierdie artikel). Die aanvangfranchisefooi sal gevolglik nie ingevolge die algemene aftrekkingsformule aftrekbaar wees nie. Alternatiewe aftrekkings moet dus vir die aanvangsfranchisefooi oorweeg word. 


\section{00RWEGING VAN ALTERNATIEWE AFTREKKINGSMOONTLIKHEDE KRAGTENS DIE WET}

Gegewe die feit dat die aanvangsfranchisefooi nie ingevolge die algemene aftrekkingsformule aftrekbaar sal wees nie, is alternatiewe aftrekkingsmoontlikhede, naamlik die Tiende Bylae tot die Wet asook artikels 11 ( $\mathrm{gC}$ ) en $1 \mathrm{l}(\mathrm{f})$ geïdentifiseer.

\subsection{Die Tiende Bylae tot die Wet}

Artikel 26B van die Wet vermeld dat die belasbare inkomste van ' $n$ olie- en gasmaatskappy ingevolge die Tiende Bylae bepaal moet word (Huxham \& Haupt, 2010). Die Tiende Bylae sal slegs van toepassing wees indien die franchisehouer aan die omskrywing van ' $n$ "olie- en gasmaatskappy" soos omskryf in paragraaf 1 van die Tiende Bylae voldoen.

'n "Olie- en gasmaatskappy" word omskryf as enige maatskappy wat - (i) enige olie- en gasreg hou; of (ii) in opsporing en produksie by enige olie- en gasreg betrokke is. " $n$ "Olie- en gasreg" beteken - (a) enige verkennings-, tegniese samewerkingspermit, eksplorasiereg of produksiereg soos omskryf in artikel 1 van die Wet op die Ontwikkeling van Minerale en Petroleumhulpbronne, nr. 28 van 2002; of (b) enige nuwe eksplorasie- of produksiereg verkry as gevolg van die omskepping van 'n ouerreg.

Die franchisehouer tree egter as kleinhandelaar op namens die petroleummaatskappy en verkoop dus die maatskappy se klaarprodukte (onder andere brandstof, smeermiddels en

kruideniersware). Die franchisehouer besit dus geen verkennings-, tegniese samewerkingspermit, eksplorasiereg of produksiereg soos beoog word in artikel l van die Wet op die Ontwikkeling van Minerale en Petroleumhulpbronne nie. Die franchisehouer hou met ander woorde geen olie- en gasreg soos beoog word in die Tiende Bylae nie. Daarbenewens is die franchisehouer ook nie betrokke by die opsporing of produksie van sodanige reg nie en hoef nie noodwendig as 'n maatskappy handel te dryf nie. Die Tiende Bylae bied gevolglik geen alternatiewe aftrekkingsmoontlikhede aan die franchisehouer vir doeleindes van hierdie artikel nie.

\subsection{Artikel $11(\mathrm{gC})$ - verkryging van intellektuele eiendom}

Artikel $11(\mathrm{gC})$ bied ' $\mathrm{n}$ aftrekking vir onkoste wat aangegaan is vir die verkryging van verskillende soorte intellektuele eiendom (gelys in artikel $11(\mathrm{gC})(\mathrm{i})$ - (v)). Ingevolge ' $n$ franchiseooreenkoms berus eienaarskap van intellektuele eiendom ten alle tye by die franchisegewer en verkry die franchisehouer slegs die reg van gebruik van die intellektuele eiendom. Artikel 11 (gC) sal in hierdie opsig gevolglik nie van toepassing wees nie.

Die vraag ontstaan dan of die fooi as eiendom van 'n soortgelyke aard tot intellektuele eiendom beskou kan word, met ander woorde, kan die betaling van die fooi op sigself as intellektuele eiendom in eie reg beskou word. Behoorlik geïnterpreteer, moet eiendom om soortgelyk van aard te wees, die fundamentele en eiesoortige eienskappe en kenmerke van die spesifieke geïdentifiseerde intellektuele eiendom onder bespreking besit; geringe of oppervlakkige ooreenkomste sal nie voldoende wees nie. Dit sinsnede word geag die intellektuele eiendom in te sluit wat nie onder die tersaaklike wetgewing geregistreer is nie, maar deur die eienaar daarvan op dieselfde manier as sodanige handelsmerke, ontwerpe, geheime formules en prosesse hanteer word (De Koker, 2008). Te oordeel aan die genoemde vereistes word daar egter aan die 
hand gedoen dat die regte wat aan die fooi gekoppel is nie die fundamentele kenmerke en eienskappe wat aan intellektuele eiendom gekoppel is, soos hierbo bedoel, besit nie. Die fooi self sal dus na alle waarskynlikheid nie as "eiendom van 'n soortgelyke aard" tot intellektuele eiendom vir doeleindes van artikel $1 \mathrm{l}(\mathrm{gC})$ beskou word nie. Geen aftrekking is dus ingevolge artikel $11(\mathrm{gC})$ beskikbaar nie.

\subsection{Artikel 11(f) - Huurpremies}

Artikel 11 (f) bied ' $n$ aftrekking ten opsigte van ' $n$ huurpremie wat deur ' $n$ huurder aan ' $n$ verhuurder betaal word. Die wese en werking van ' $n$ franchise-ooreenkoms stem in baie opsigte met dié van ' $n$ huurooreenkoms ooreen. ' $n$ Franchise- en huurooreenkoms verleen albei aan die franchisehouer/huurder die reg van gebruik van die franchisegewer/verhuurder se eiendom. Die ooreenkomste bevat bepalings en voorwaardes waarvolgens die franchisehouer-franchisegewerverhouding asook huurder-verhuurder-verhouding gereguleer word. Die opvallendste verskil tussen ' $n$ franchise-ooreenkoms en huurooreenkoms word dikwels gevind in die verskeie klousules wat ' $n$ franchise-ooreenkoms bevat, wat die dikwels omvattende verpligtinge en beperkinge van die franchisehouer daarstel teenoor die, gewoonlik, korter en minder gekompliseerde bepalings wat in ' $n$ gewone huurooreenkoms vervat is. Daar word aan die hand gedoen dat ' $n$ franchise-ooreenkoms in baie opsigte soortgelyk is aan ' $n$ gewone huurooreenkoms.

\subsubsection{Struktuur van artikel 11(f)}

Artikel 11(f) word deur Huxham en Haupt (2010:208) kortliks soos volg opgesom:

' $n$ Huurder word toegelaat om die premie ingevolge a 11 (f) soos volg as ' $n$ aftrekking te eis: ' $n$ bedrag betaal as ' $n$ premie (of dergelike betaling) vir die reg van gebruik van grond of geboue, of installasie of masjinerie, rolprentfilm, klankopname of verwante advertensiestukke, patente, modelle, handelsmerke of outeursregte (of dergelike intellektuele eiendom) of vir die meedeling van kennis in verband met die gebruik van die film, klankopname of verwante advertensiestukke of intellektuele eiendom soos hierbo vermeld of vir die reg van gebruik van ' $n$ artikel 12D pyplyn, kabel, ens. wat ' $n$ "geaffekteerde bate" ingevolge artikel $12 \mathrm{D}$ is.

Uit ' $n$ voorlopige ontleding van artikel $11(f)$ blyk dit dat die aanvangsfranchisefooi aan twee primêre "vereistes" moet voldoen alvorens artikel $11(f)$ van toepassing sal wees. Die eerste vereiste is of die betaling van die fooi as ' $n$ premie of teenprestasie in die aard van ' $n$ premie kwalifiseer. Die tweede vereiste is of die fooi ' $n$ betaling vir die reg van gebruik van enige van die items is wat in artikel $11(f)(i)$ - (v) gelys is. Daar is ook drie bykomende sekondêre vereistes waaraan die fooi moet voldoen alvorens artikel $11(f)$ as ' $n$ aftrekking geëis kan word. Hierdie drie sekondêre vereistes kan kortliks soos volg uiteengesit word:

(1) Daar moet op gelet word dat die ll(f)-vermindering slegs beskikbaar is wanneer ' $n$ premie vir die reg van gebruik of okkupasie van ' $n$ bate betaal is. Bedrae wat vir die algehele verkryging van ' $n$ bate betaal word, val nie binne die bestek van die vermindering nie (Stiglingh, Koekemoer, Van Schalkwyk, Wilcocks, De Swardt \& Jordaan, 2010:234). Hierdie vereiste is deur die belastinghofsake ITC 353 (1936) 9 SATC 82 en ITC 613 (1945) 14 SATC 389 ingestel.

(2) Geen vermindering ingevolge artikel $11(f)(v)(d d)$ word voorts toegestaan nie, tensy die huurpremie inkomste van die verhuurder is. 
(3) Die bate waarvoor die premie betaal is, moet by die voortbrenging van inkomste gebruik word of inkomste moet deur die huurder daaruit verkry word.

\subsubsection{Bespreking van artikel $11(f)$ se eerste primêre vereiste}

Die uitdrukking "premie of dergelike vergoeding", soos wat in paragraaf (g) van die "bruto inkomste"-omskrywing vervat en "premie of teenprestasie in die aard van 'n premie", soos wat in artikel $11(\mathrm{f})$ vervat, het volgens die Suid-Afrikaanse howe dieselfde betekenis (Turnbull $v$ CIR 1953 (2) SA 573 (A), 18 SATC 336 ('Turnbull')). Die begrippe word deur die howe in CIR v Butcher Bros (Pty) Ltd 1945 AD 301, 13 SATC 21 ('Butcher Bros') as "die vergoeding wat vanaf ' $n$ huurder aan ' $n$ verhuurder, in kontant of andersins, onderskeibaar en addisioneel of in die plek van huur oorgaan", omskryf (vertaling). Die vergoeding moet voorts 'n bepaalbare geldwaarde hê en nie bloot ' $n$ denkbeeldige waarde nie.

Brownlie en Jooste (1995:241) voer egter aan dat die onderskeid tussen "huur" en "premie" met verloop van tyd onduidelik geword het. Huur word as ' $n$ som geld betaalbaar as vergoeding vir die gebruik en genot van gehuurde eiendom omskryf. Huur word vir die werklike gebruik van die eiendom, en nie vir die reg om dit te gebruik nie, betaal. Hierdie onderskeid is van kardinale belang. ' $n$ Belangrike punt om in gedagte te hou, is dat die betalingsmetode van die huur nie, per $s e$, die aard van dit wat betaal word verander nie, hetsy of die huur in een of meer paaiemente betaal word of vooruit of agterna betaalbaar is. Dit is gebiedend deur die Suid-Afrikaanse howe bepaal dat huur wat deur ' $n$ huurder betaal word, deel van die koste van die bedryf van sy inkomstegenererende struktuur vorm en as sodanig inkomste van aard is (volgens Turnbull).

Brownlie en Jooste (1995:242) beklemtoon die noodsaaklikheid om tussen ' $n$ huurbetaling aan die een kant en die betaling van ' $n$ bedrag om huurregte te bekom aan die ander kant, waarvan die gevolg die betaling van huur is, te onderskei. Daar word aangevoer dat laasgenoemde ' $n$ kapitaalbedrag verteenwoordig deurdat dit die huurder se inkomstegenererende struktuur uitbrei of verbeter. Aangesien ' $n$ premie normaalweg as kapitaal van aard deur die SuidAfrikaanse howe beskou word, het talle belastingpligtiges probeer om vooruitbetaalde huur kunsmatig as ' $n$ premie te etiketteer om sodoende die bruto inkomste-omskrywing in artikel 1 van die Wet te omseil (Brownlie \& Jooste, 1995:247). Die Wetgewer en Fiskus het gevolglik die nodigheid gesien om ' $n$ onderskeid te tref tussen ' $n$ premie (kapitaal van aard) en vooruitbetaalde huur (inkomste van aard). Brownlie en Jooste (1995:245) verduidelik dat die insluiting van paragraaf $(\mathrm{g})$ by die bruto inkomste-omskrywing en artikel $11(\mathrm{f})$ van die Wet grootliks ' $n$ poging van die Wetgewer was om hierdie tipe skyntransaksies te identifiseer en te neutraliseer. Die howe sal dus uit die aard van die saak op die ware bedoeling van die partye betrokke by die transaksie fokus (die toepassing van die "wese-bo-vorm"-beginsel).

Wat die omskrywing van ' $n$ premie betref, redeneer Brownlie en Jooste, (1995:248) dat die bewoording wat in die Butcher Bros hofsaak gebruik word om die begrip te omskryf, dubbelsinnig en verwarrend is. Brownlie en Jooste (1995:248) bevraagteken die gebruik van die woorde "in lieu", oftewel, "in plaas van" om 'n premie te omskryf. 'n Premie kan nie terselfdertyd iets wees bo en behalwe huur en iets in plaas van huur nie. Brownlie en Jooste is van mening dat 'n premie iets addisionee/ tot ' $n$ huurbetaling is. Indien 'n premie dieselfde as huur is, soos deur die "in plaas van huur"-deel van die omskrywing geïmpliseer word, word die vraag gestel of daar dan enigsins onderskeid getref moet word tussen ' $n$ premie en ' $n$ huurbetaling. As dit dieselfde is, behoort beide items dan ingevolge die algemene aftrekkingsformule aftrekbaar te wees, aangesien ' $n$ huurbetaling as inkomste van aard beskou word. Indien dit die geval is, is daar gevolglik geen nodigheid vir ' $\mathrm{n}$ spesiale aftrekking soos in artikel $1 \mathrm{l}(\mathrm{f})$ vervat nie. In die hofsaak Levy v Commissioner for Inland Revenue 5 SATC 1191930 NLR ("Levy") het die hof aanvaar dat 
die begrip "premie of dergelike vergoeding" iets bo en behalwe die huur van die eiendom was (Brownlie \& Jooste, 1995:251). Hierdie interpretasie van die premie-begrip is ook deur De Wet, J in die belastinghofsaak ITC 72818 SATC 94 ondersteun.

In Australië word 'n premie gewoonlik as 'n bedrag wat deur 'n potensiële huurder aan die verhuurder betaal word om die verhuurder oor te haal om die huur van 'n spesifieke eiendom aan die huurder toe te ken of toe te wys beskou. Byvoorbeeld, 'n persoon wat angstig is om ' $n$ spesifieke eiendom te huur, kan die eienaar of verhuurder ' $n$ addisionele eenmalige enkelbedrag (bo en behalwe die ooreengekome markverwante huur) aanbied om die huur te bekom (Woellner, Barkoczy, Murphy \& Evans, 2004:387). Die woord "premium" word in afdeling 26AB van die Australiese Income Tax Assessment Act 1936 as "consideration payable where the consideration is in the nature of a premium for or in connexion with the grant or the assignment of a lease; or for or in connexion with an asset to the grant or assignment of a lease; but does not include an amount in respect of goodwill or a license" omskryf.

Die Australiese howe omskryf dus ' $n$ premie as ' $n$ vergoeding ontvang (of betaal) vir die toekenning of toewysing van ' $n$ huur. Die howe beskou gewoonlik hierdie premie as kapitaal van aard vanweë die feit dat die premie in 'n sekere sin gekoppel is aan die toegang tot, eerder as die gebruik, van die eiendom (Case C2 71 ATC 8, per FE Dubout (Voorsitter) op bladsy 10, G Thompson (Lid) op bladsy 12). Die hof tref dus ' $n$ duidelike onderskeid tussen ' $n$ huurpremie en 'n gewone huurbetaling volgens $F C$ of $T \mathrm{v}$. Krakos Investments Pty Ltd 96 ATC 4063. In Nixon v. Doney (1960) NSWR 2 het die hof ' $n$ huurpremie as die aankoopprys van die voordeel wat bekom word ingevolge die huurooreenkoms beskou. Hierdie beskouing verleen gevolglik aan die huurpremie sy kapitale aard. Dit is duidelik uit bostaande bespreking dat die Australiese howe ' $n$ premie as iets addisioneel of bo en beha/we huur beskou.

\section{a) Beoordeling van die aanvangsfranchisefooi aan die hand van die eerste primêre vereiste}

Die aanvangsfooi is ' $n$ nie-terugbetaalbare enkelbedrag betaalbaar bo en behalwe die herhalende franchisefooie, vir die reg van gebruik van die franchisegewer se stelsels, toerusting, handelsmerke, bedryfsgeheime en -kennis. Die feit dat die fooi na alle waarskynlikheid as ' $n$ kapitale onkoste beskou sal word, versterk die argument dat die bedrag as ' $n$ premie kwalifiseer weens die feit dat ' $n$ premie hoofsaaklik as ' $n$ kapitaalitem beskou word. Die fooi is voorts teenprestasie bo en behalwe die normale herhalende franchisefooie. Indien dit die ware bedoeling van die franchisehouer en franchisegewer is dat die betaling van die aanvangsfranchisefooi ' $n$ teenprestasie vir die toekenning van die reg van gebruik van die franchisegewer se eiendom is, sal die howe daaraan gehoor gee en die aanvangsfranchisefooi gevolglik as ' $n$ premie (soos deur artikel 11 (f) beoog) beskou. Hieruit volg dat die aanvangsfranchisefooi die eerste primêre toets van artikel ll(f) slaag.

\subsubsection{Bespreking van artikel $11(f)$ se tweede primêre vereiste}

Die vertrekpunt van hierdie vereiste is dat die reg van gebruik met die betaling van die premie bekom moet word vir items wat ingevolge artikel 11 (f) gelys is. Klem word dus gelê op die "reg van gebruik" asook die soort items waarvoor die premie betaal word. In die veronderstelling dat die aanvangsfooi "n "premie" is soos omskryf, word daar voorts ondersoek ingestel na die doel van die fooi. Die bewoording wat in die spesifieke franchise-ooreenkoms gebruik word, is dus van kardinale en deurslaggewende belang ten einde vas te stel of die fooi vir ' $n$ aftrekking ingevolge artikel 11 (f) kwalifiseer. Vir doeleindes van hierdie artikel is ' $n$ standaardfranchiseooreenkoms van elk van drie van Suid-Afrika se sewe verskillende petroleummaatskappye bekom. Bestudering van die verskillende franchise-ooreenkomste behoort dus die item(s) 
waarvoor die fooi tipies betaal word, te identifiseer. Die fooi hoef nie noodwendig ' $n$ betaling vir die reg van gebruik te wees nie. Kommentaar word telkens gelewer ten opsigte van die struktuur en bewoording van die ooreenkomste en of die fooi aan die tweede primêre vereiste voldoen. Weens ' $n$ vertroulikheids-vereiste word skuilname vir die betrokke petroleummaatskappye gebruik.

\section{a) Petroleummaatskappy A:}

"...' $A$ ' hereby grants to the Franchisee..., the right and authority and license

to operate an 'A' Franchise operation..." (Franchise-ooreenkoms A, 2010).

Uit bostaande word die fooi as teenprestasie vir die reg en vergunning om 'n spesifieke franchise te kan bedryf, betaal. Die reg soos deur die bostaande franchise-ooreenkoms beoog word, is ' $n$ reg om besigheid te kan doen en nie per se' $\mathrm{n}$ reg om iets te gebruiknie. Hierdie bewoording dui daarop dat die betaling van die fooi vir die verkryging van ' $n$ reg is, wat impliseer dat die fooi kapitaal van aard is. In sodanige geval slaag die fooi nie die eerste sekondêre vereiste van artikel $11(f)$ nie. Dit is gevolglik onduidelik of die reg wat ontstaan, ' $n$ gewone eiendomsreg (met ander woorde ' $n$ besitreg sonder gebruiksreg) is en of dit ' $n$ reg van gebruik is (soos deur artikel 11 (f) beoog word). Indien dit bloot eersgenoemde reg is, blyk dit dat daar geen aftrekking kragtens die huidige Wet bestaan nie.

Bostaande bewoording van die franchise-ooreenkoms maak dit vir die franchisehouer potensieel moeilik om te argumenteer dat die fooi ' $n$ betaling vir die reg van gebruik is, soos deur artikel $11(f)$ beoog word, indien dit nie as sodanig gestipuleer is nie. Bo en behalwe hierdie probleem, lys hierdie spesifieke ooreenkoms nie enige items waarvoor die reg van gebruik (indien enige) toegeken word nie. Per implikasie lei dit daartoe dat, in hierdie geval, die franchisehouer hom/haar nie op die werking van artikel 11 (f) kan beroep nie en verder ook nie op die werking van artikel 11 (a) sal kan staatmaak nie vir redes wat reeds genoem is.

\section{b) Petroleummaatskappy B:}

"The franchisor hereby grants to the franchisee... a franchise to operate a ' $B$ ' franchise store on the premises and a license to use the ' $B$ ' franchise system including the 'B' franchise identifications" (Franchise-ooreenkoms B, 2010).

Uit bostaande word die fooi vir die bedryf van die franchise en ' $n$ lisensie om die franchise se stelsels en intellektuele eiendom te gebruik, betaal. Die lisensie word dus geag ' $n$ reg van gebruik te wees. Die bewoording plaas meer klem op die gebruik van hierdie items, wat ook gelys word as die sogenaamde "kwalifiserende" items ingevolge artikel ll(f). ' $n$ Potensiële struikelblok vir die aftrekking van die fooi in sy geheel, is die feit dat dit in hierdie spesifieke ooreenkoms ' $n$ tweeledige doel het, aangesien dit deels vir die reg van bedryf en deels vir die reg van gebruik betaal word.

Daar word aan die hand gedoen dat daar ' $n$ verskil is tussen die toestaan van ' $n$ reg om ' $n$ besigheid as ' $n$ franchise te kan beoefen en die toestaan van ' $n$ reg om items van die franchise te kan gebruik. Alhoewel albei hierdie regte as kapitaal van aard beskou behoort te word, kan laasgenoemde reg moontlik vir ' $n$ aftrekking ingevolge artikel 11 (f) kwalifiseer, aangesien dit op die reg van gebruik fokus, en eersgenoemde reg nie. Dit is egter ' $n$ betwisbare vraag waarvan die skeidslyn nie altyd so duidelik is nie. Met inagneming van bostaande blyk dit op die oog af of die bewoording en doel van hierdie fooi moontlik aan die tweede primêre vereiste sal voldoen en dus duideliker en doeltreffender as die voorafgaande ooreenkoms gestruktureer is. 


\section{c) Petroleummaatskappy C:}

"Licence Fee - "...the Dealer shall pay to the Company a Licence Fee, which fee shall entitle the Dealer to market the Company's Automotive Products and to use the Company's brand names, logos and trademarks associated therewith" (Franchise-ooreenkoms C, 2010).

Soortgelyk aan die vorige geval, dui bostaande uittreksel daarop dat die fooi tweedoelig is, naamlik dat dit betaal is (1) as teenprestasie vir die reg om Franchise $C$ se produkte te bemark; en (2) as teenprestasie vir die reg van gebruik van die franchise se intellektuele eiendom. Die tweede doel van die fooi voldoen aan die tweede primêre vereiste van artikel ll(f), aangesien die fooi betaal word vir die reg van gebruik van intellektuele eiendom soos gestel deur artikel ll(f)(iii). Die eerste doel blyk egter nie aan die tweede primêre vereiste te voldoen nie, aangesien dit nie op die reg van gebruik van enige van die items wat in artikel 11 (f) gelys is, dui nie. Voorts wil dit voorkom of dit op 'n verkryging van ' $n$ bate dui, naamlik ' $n$ reg tot bemarking. Indien dit die geval is, slaag hierdie gedeelte van die fooi nie die eerste sekondêre vereiste nie. Aangesien hierdie deel van die fooi kapitaal van aard is, blyk ' $n$ aftrekking ingevolge artikel 11(a) ook nie moontlik te wees nie.

Huxham en Haupt (2010) voer aan dat ' $n$ betaling wat gemaak word ten einde ' $n$ bate te gebruik, onderskei moet word van ' $n$ betaling wat gemaak word ten einde die blywende reg om die bate te gebruik, te bekom. So 'n reg sal 'n ontasbare bate wees en sal gewoonlik kapitaal van aard wees, aangesien dit deel van die belastingpligtige se inkomstegewende struktuur sal uitmaak. Die aftrekking van die totale fooi word dus deur die feit dat ' $n$ gedeelte daarvan na alle waarskynlikheid nie as aftrekking ingevolge artikel ll(f) of $11(\mathrm{a})$ geëis sal kan word nie, bemoeilik.

\subsubsection{Bespreking van bykomende aangeleenthede voortspruitend uit die toepassing van artikel 11(f)}

Die beoordeling van die aanvangsfooi aan die hand van artikel 11 (f) het twee addisionele aangeleenthede uitgelig wat verdere bespreking verlang. Die eerste aangeleentheid is die geval waar die fooi betaal word vir die reg van gebruik van ' $n$ item wat nie spesifiek in artikel 11 (f) gelys word nie. Waar ' $n$ franchise-ooreenkoms nie die spesifieke tipes intellektuele eiendom soos gelys in artikel $1 \mathrm{l}(\mathrm{f})$ stipuleer nie, ontstaan die vraag of die betaling van die fooi as ' $\mathrm{n}$ teenprestasie vir die reg van gebruik van enige ander goed wat van 'n dergelike aard is, kan kwalifiseer. Byvoorbeeld, indien die fooi ' $n$ betaling is vir onder andere die reg van gebruik van die franchise se naam, die gebruik van die voordele wat voortspruit uit die klandisiewaarde wat gekoppel is aan die franchise se goeie naam, of die gebruik van die franchise se bedryfsgeheime, onstaan die vraag of hierdie items (aangesien dit nie spesifiek deur artikel 11 (f) gelys word nie) kan kwalifiseer as "enige ander goed wat van ' $n$ dergelike aard is". Daar moet dus vasgestel word wat die sinsnede "enige ander goed wat van "n dergelike aard is", beteken en daarmee saam hoe wyd (of hoe eng) hierdie sinsnede geïnterpreteer kan word. Die tweede aangeleentheid handel oor die verdeling van ' $n$ enkelbedrag in verskillende komponente vir aftrekkingsdoeleindes. Byvoorbeeld, soos in die ontleding van Petroleummaatskappy B en C se franchise-ooreenkomste, het dit voorgekom of die doel van die fooi tweeledig is.

\section{a) Die betekenis en interpretasie van die sinsnede "enige ander goed wat van 'n dergelike aard is"}

Die sinsnede word nie deur die Inkomstebelastingwet omskryf nie. Volgens Clegg en Stretch (2008), moet die gewone woordeboekbetekenis van 'n woord daaraan gekoppel word in die geval 
waar ' $n$ woord nie deur die Wet omskryf word nie, tensy daar ' $n$ teenstrydige bedoeling blyk te wees (volgens Mincer Motors Ltd $v$ Commissioner of Customs and Excise 1958 (1) SA 652 (T)).

Die gewone woordeboekbetekenis van die woord "dergelik" volgens die Verklarende Handwoordeboek van die Afrikaanse Taal (1994:137) is: "soortgelyk, net soos wat vroeër genoem is". Die kernbegrip wat dus na vore kom, is dat die woord na "iets soortgelyks" verwys. In watter mate "iets soortgelyks" is, is egter " $\mathrm{n}$ kwessie van interpretasie en graad. Ingevolge die benadering wat deur die Suid-Afrikaanse howe gevolg word, impliseer dit dat die betekenis van die begrip "eiendom soortgelyk aan intellektuele eiendom" soos gebruik in artikel $11(\mathrm{f})$ dieselfde betekenis as die ooreenstemmende begrip soos gebruik in artikel $1 \mathrm{l}(\mathrm{gC})$ behoort te dra (Taljaard, 2001:62). Verder moet daarop gelet word dat die sinsnede, soos wat dit gebruik word in artikel $11(\mathrm{f})$, gekoppel is aan die items wat ingevolge artikel $11(\mathrm{f})$ (iii) gelys is, naamlik sekere tipes intellektuele eiendom. Die sinsnede moet slegs binne daardie konteks oorweeg word, en is nie aan enige van die ander items wat in artikel $11(f)(i)-(v)$ gelys is, gekoppel nie. Die parameter waarbinne die sinsnede van krag is, is dus duidelik en onweerlegbaar.

Die antwoord in watter mate' $n$ item soortgelyk is aan intellektuele eiendom kan moontlik gevind word in die toepassing van die ejusdem generis en noscitur a sociis beginsel en stelreël wat deur die Suid-Afrikaanse howe gebruik word. Met betrekking tot die ejusdem generis beginsel verwys ' $n$ afdeling van ' $n$ statuut in sekere gevalle na besondere items met ' $n$ gemeenskaplike karaktereienskap, wat van hierdie items ' $n$ genus maak, en hierdie besondere items word dikwels deur algemene woorde of sinsnedes gevolg (Clegg \& Stretch, 2008). Waar so ' $n$ lys van items (soos handelsmerke, kopieregte en patente) ' $n$ genus vorm en deur ' $n$ algemene uitdrukking gevolg word, word die algemene uitdrukking (in die afwesigheid van ' $n$ teenstrydige bedoeling deur die statuut) vertolk as ejusdem generis om slegs ander items van dieselfde klas as wat die besondere woord(e) is, in te sluit.

Die ejusdem generis beginsel word in wisselwerking met die noscitur a sociis stelreël toegepas. Ingevolge die stelreël noscitur a sociis, word twee of meer woorde wat vatbaar is vir analoë betekenisse, saam gebruik. Hierdie woorde neem mekaar se "kleur" aan, dit wil sê, die meer algemene word beperk tot die betekenis soortgelyk aan die minder algemene (Van Schalkwyk, 2010:5). Volgens Botha (1998:128) word woorde dus geken aan die ander waarmee hulle verskyn. Byvoorbeeld, die woorde "intellektuele eiendom" word in hierdie situasie as die minder algemene woorde beskou aangesien dit na spesifieke soort items verwys. Items "soortgelyk of van " $n$ dergelike aard" is van " $n$ meer algemene aard, maar sal binne konteks die "kleur" van die minder algemene woorde, naamlik die van intellektuele eiendom, aanneem. Dit sal dus nouliks aan hierdie woorde verwant wees.

Hieruit volg dat die sinsnede "enige ander goed wat van "n dergelike aard is" vir doeleindes van artikel $11(f)$ eng interpreteer moet word aan die hand van die klas van items waarmee dit gepaardgaan, naamlik dié van intellektuele eiendom. Dit blyk dus dat items soos die bedryfsgeheime en geheime formules en -prosesse van ' $n$ franchisegewer heel waarskynlik as items soortgelyk aan intellektuele eiendom beskou behoort te word, gegewe die feit dat hierdie items geskep is deur die intellektuele vermoëns van die franchisegewer, ontasbaar is en die vertroulikheid, werking asook eienaarskap daarvan beskerm word deur die franchiseooreenkoms (waarvoor normale kontrakteregbeginsels sal geld). Hierdie tipe items het dus dieselfde fundamentele eienskappe as die ander items van intellektuele eiendom wat in artikel 11 (f)(iii) gelys word. Dit is egter onwaarskynlik dat die ander items wat vroeër as voorbeelde gelys is, sal kwalifiseer, aangesien dit nie die karaktereienskappe van intellektuele eiendom toon nie. 


\section{b) Die verdeling van ' $n$ enkelbedrag in afsonderlike komponente vir aftrekkingsdoeleindes}

Die doel waarmee ' $n$ enkelbedrag aangegaan word, kan meerdoelig wees. Waar een doel nie duidelik na vore tree nie, word die vraag gestel of die enkelbedrag in verskillende komponente verdeel kan word ten einde vir verskillende aftrekkings te kwalifiseer. Alhoewel die verdeling van onkoste in 'n kapitaal- en inkomste-element nie uitdruklik deur die Wet voorgeskryf of verbied word nie, het die Suid-Afrikaanse howe al in verskeie hofsake dit goed gedink om die toedeling van ' $n$ onkoste tussen ' $n$ kapitaal- en inkomste-element toe te laat, op voorwaarde dat, gegewe die spesifieke feite van die scenario, die toedeling billik en redelik gemaak word. Ondersteuning van die toedeling van onkoste in gepaste situasies word in verskeie uitsprake van regters gevind, onder andere in Secretary for Inland Revenue $v$ Guardian Assurance Holdings (SA) Ltd 38 SATC 111 ("Guardian"), Borstlap v Sekretaris van Binnelandse Inkomste 43 SATC 195 ("Borstlap"), en Commissioner for Inland Revenue v Nemojim (Pty) Ltd 45 SATC 241 ("Nemojim"). Die deel van die fooi wat vir ' $n$ aftrekking kwalifiseer, sal dus aftrekbaar wees.

\section{c) Beoordeling van die aanvangsfranchisefooi aan die hand van die tweede primêre vereiste}

Gegewe die voorafgaande, gedetailleerde bespreking kan die aanvangsfranchisefooi aan die hand van die tweede primêre vereiste soos volg beoordeel word:

- Waar die bewoording van die franchise-ooreenkoms spesifiek na die doel van die aanvangsfranchisefooi verwys as die teenprestasie vir die reg van gebruik van ' $n$ franchise se eiendom, wat in artikel 11 (f) gelys is, behoort die fooi aan die tweede primêre vereiste van artikel $1 l(f)$ te voldoen. Alle items waarvoor die fooi betaal word, sal nie noodwendig vir ' $n$ aftrekking ingevolge artikel 11 (f) kwalifiseer nie.

- Waar die doel van die fooi egter meerdoelig is, kan ' $n$ toedeling (indien billik en regverdig) tussen die gedeeltes van die fooi wat wel kwalifiseer vir ' $n$ aftrekking ingevolge artikel $11(\mathrm{f})$ en die wat vir ander aftrekkings (indien enige) kwalifiseer, gemaak word.

- Die sinsnede "van 'n dergelike aard" het slegs betrekking op intellektuele eiendom en sal aan die vereistes wat deur die howe ten opsigte van hierdie aangeleentheid bepaal is, moet voldoen ten einde vir ' $n$ aftrekking ingevolge artikel 11 (f) te kwalifiseer.

\subsubsection{Oorweging van artikel $23 \mathrm{I}$ - verbod op die aftrekking van onkoste ten opsigte van besmette immateriële goedere}

Al voldoen die aanvangsfooi aan beide die primêre en sekondêre vereistes van artikel 11(f), moet die werking van artikel 231 ook oorweeg word. Artikel 23 I verbied die aftrekking van sekere onkoste wat deur ' $n$ belastingpligtige aangegaan is vir die gebruik of reg van gebruik van besmette immateriële goedere in die mate wat die bedrag nie inkomste verteenwoordig in die hande van die ontvanger daarvan nie.

Besmette immateriële goedere word in artikel 231 omskryf en beteken opsommenderwys, volgens Huxham en Haupt (2010:537), enige patent, model, handelsmerk, outeursreg, ontdekking of soortgelyke eiendom of kennis in verband met die gebruik van enige van hierdie intellektuele eiendom en wat aan een van die volgende vier vereistes voldoen: (1) dit was die eiendom van 'n eindgebruiker of ' $n$ verbonde persoon aan die eindgebruiker; (2) dit is die eiendom van ' $n$ belasbare persoon; (3) ' $n$ wesenlike deel van die intellektuele eiendom is deur ' $n$ belasbare persoon gebruik in die bedryf van ' $n$ besigheid terwyl daardie intellektuele eiendom deur ' $n$ belasbare persoon besit is en die eindgebruiker van daardie eiendom daardie besigheid of ' $n$ wesenlike deel daarvan as ' $n$ lopende saak verkry het; of (4) die intellektuele eiendom is deur 
die eindgebruiker (of ' $n$ verbonde belasbare persoon) ontdek, ontwerp, ontwikkel, geskep of vervaardig en die eindgebruiker (tesame met ' $n$ verbonde belasbare persoon) hou minstens $20 \%$ van die deelnemende regte in ' $n$ persoon aan wie of van wie ' $n$ bedrag ontvang is of toegeval het uit hoofde van die verlening van die reg om die intellektuele eiendom te gebruik.

Die begrippe "eindgebruiker" en "belasbare persoon" word in artikel 231 omskryf. Die intellektuele eiendom waarvan die franchisehouer die reg van gebruik geniet, kan moontlik aan die omskrywing van besmette immateriële goedere voldoen met die gevolg dat artikel 231 moontlik van toepassing kan wees (met dien verstande dat die franchisegewer aan een van die vier vereistes van artikel 231 wat hierbo gelys is) voldoen. Indien die ontvangs van die aanvangsfranchisefooi egter belasbare inkomste sou uitmaak in die hande van die franchisegewer, is die artikel nie van toepassing nie. Die franchisehouer moet dus in gedagte hou dat die belasbaarheid van die aanvangsfranchisefooi in die hande van die franchisegewer van kardinale belang is ten einde te bepaal of die fooi(e) aftrekbaar is, waar die fooie betaal word vir die gebruik of reg van gebruik van immateriële goedere soos omskryf in artikel 23I. Sou artikel 23 I van toepassing wees, sal die fooi(e) slegs aftrekbaar wees in die mate wat dit in die hande van die franchisegewer belasbaar is.

\subsubsection{Werking van artikel $11(f)$}

Indien die aanvangsfooi vir ' $n$ aftrekking ingevolge artikel 11 (f) kwalifiseer en artikel 23 I nie van toepassing is nie, kom die werking van die artikel kortliks daarop neer dat die premie in jaarlikse paaiemente aftrekbaar is. Die paaiemente word op die termyn van die huurooreenkoms gebaseer, dit wil sê die totale premie gedeel deur die aantal jare van die huurooreenkoms (beperk tot ' $n$ maksimum van 25 jare). Die aftrekking word vir 'n gedeelte van ' $n$ jaar toegedeel, bereken vanaf die aanvang van die huurooreenkoms (of franchise-ooreenkoms).

\section{00RWEGING VAN ALTERNATIEWE AFTREKKINGSMOONTLIKHEDE INGEVOLGE AUSTRALIESE INKOMSTE-BELASTINGWETGEWING}

Australië se inkomstebelastingstruktuur is in ' $n$ groot mate met dié van Suid-Afrika vergelykbaar (volgens regter Wunsh in die hofsaak CIR v Manganese Metal Co (Pty) Ltd [1996] 58 SATC 1). Die Australiese inkomstebelastingwetgewing van toepassing vir doeleindes van hierdie artikel word in die "Income Tax Assessment Act 1997" (ITAA97) en "Income Tax Assessment Act 1936" (ITAA36) vervat. Die twee wette word gevolglik in wisselwerking met mekaar gebruik en toegepas.

Die bepalings waaronder aftrekkings geëis kan word, bestaan uit ' $n$ algemene aftrekkingsbepaling wat in artikel 8-1 ITAA97 vervat is, asook ' $n$ wye reeks van spesifieke aftrekkings wat deurgaans ITAA97 en ITAA36 voorkom (Woellner et al., 2004:685). 'n Aftrekking kan slegs geëis word indien dit aan die vereistes van óf ' $n$ spesifieke aftrekkingsbepaling óf die algemene aftrekkingsbepaling voldoen en verder nie deur enige bepaling(s) van die inkomstebelastingwette eksplisiet verbied word nie. 'n Proses van eliminasie (soortgelyk aan die Suid-Afrikaanse een) moet dus gevolg word ten einde te bepaal of ' $n$ aftrekking geëis kan word, al dan nie.

' $n$ Bestudering van die Australiese algemene aftrekkingsbepaling het verskeie ooreenkomste met dié van die Suid-Afrikaanse algemene aftrekkingsformule getoon met die gevolg dat die aanvangsfranchisefooi na alle waarskynlikheid nie vir ' $n$ aftrekking ingevolge die algemene 
aftrekkingsbepaling sal kwalifiseer nie. Die hoofrede hiervoor is die feit dat die fooi in Australië ook as kapitaal van aard beskou sal word en die algemene aftrekkingsbepaling onkoste van 'n kapitale aard as aftrekking verbied.

$\mathrm{Na}$ die bestudering van die Australiese inkomstebelastingwette is twee moontlikhede waaronder 'n aftrekking potensieel geëis kan word, geïdentifiseer, naamlik "blackhole"-kapitaalonkoste en tantièmebepalings. Hierdie alternatiewe word vervolgens bespreek.

\section{1 "Blackhole"-kapitaalonkoste}

Sedert 1 Julie 2001 is daar ingevolge artikel 40-880 ITAA97 sewe kategorieë van besigheidsverwante kapitaalonkoste wat oor vyf jaar aftrekbaar is (Woellner et al., 2004:851). Hierdie onkoste was nie aftrekbaar onder die algemene aftrekkingsformule nie vanweë hul kapitale aard, ook nie onder enige ander bepaling in die Australiese inkomstebelastingwette nie. Hierdie onkoste het in 'n spreekwoordelike "donker gat" ("blackhole") geval. Volgens Woellner et al. (2004:851) bied artikel 40-880 ITAA97 ' $n$ laaste opsie as ' $n$ aftrekking, mits hierdie onkoste nie alreeds aftrekbaar is onder enige ander bepaling wat in die inkomstebelastingwette vervat is nie, en onder een van die sewe kategorieë val. Een van die sewe kategorieë van onkoste waaronder die aanvangsfranchisefooi moontlik kan ressorteer, is onkoste om die besigheidstruktuur te skep. Die ander ses kategorieë is egter nie van toepassing nie.

Die aanvangsfranchisefooi word in wese aangegaan om die franchisehouer die geleentheid te bied om ' $n$ franchise te kan bedryf. Daaruit volg dat die fooi tog in effek aangegaan word om die franchisehouer se besigheidstruktuur, naamlik die franchise, te skep waarbinne sy sakeaktiwiteite uitgevoer kan word. Daar bestaan egter twyfel of dit ingevolge artikel 40-880 ITAA97 aftrekbaar is volgens Woellner et al. Woellner et al. (2004:851) voer aan dat hierdie spesifieke kategorie van onkoste slegs kapitaalonkoste is wat deur belastingpligtiges aangegaan is om die besigheidstruktuur wetlik te vestig, byvoorbeeld om 'n maatskappy te stig, vennootskap te vorm of ' $n$ trust te skep; hierdie onkoste sluit egter nie enige onkoste met betrekking tot huur of ander wettige of ekwiteitsregte, franchisefooie of die verkryging van klandisiewaarde in nie. Met ander woorde, indien die onkoste ' $n$ franchisefooi is, word dit gediskwalifiseer. Dit blyk dus dat die aanvangsfranchisefooi nie as 'n "blackhole"-onkoste ingevolge artikel 40-880 ITAA97 aftrekbaar sal wees nie. Daar is egter tot op hede nog geen regspraak wat hierdie siening bevestig of verwerp nie. Artikel 40-880 ITAA97 word gevolglik as 'n moontlike aftrekkingsbepaling waaronder die aanvangsfranchisefooi geëis kan word, beskou.

\subsection{Tantième-aftrekking}

Artikel 26-25(3) van ITAA97 bied ' $n$ aftrekking vir ' $n$ tantième en lees soos volg:
"26-25 Interest or royalty - (3) If: (a) apart from subsection (1) or (2), you can deduct interest (within the meaning of Division 11A of Part III of the Income Tax Assessment Act 1936) or a *royalty for an income year; and (b) the *withholding tax payable for the interest or the royalty is paid; you can deduct the interest or royalty for that income year."

Subartikel (1) en (2) vereis die betaling van teruggehoue belasting deur die betaler van die rente of tantième. Indien die betaling aan die omskrywing van tantième (soos binne ' $n$ Australiese konteks beoog) en aan die vereistes van artikel 26-25 voldoen, behoort die aanvangsfranchisefooi as aftrekking geëis te kan word. 
Artikel 6-1 ITAA36 bevat ' $n$ omvattende omskrywing van tantième met die volgende gedeeltes wat vir doeleindes van hierdie studie van toepassing is:

"6-1 royalty or royalties includes any amount paid or credited, however described or computed, and whether the payment or credit is periodical or not, to the extent to which it is paid or credited, as the case may be, as consideration for: (a) the use of, or the right to use, any copyright, patent, design or model, plan, secret formula or process, trademark, or other like property or right; (b) the use of, or the right to use, any industrial, commercial or scientific equipment; (c) the supply of scientific, technical, industrial or commercial knowledge or information; (d) the supply of any assistance that is ancillary and subsidiary to, and is furnished as a means of enabling the application or enjoyment of, any such property or right as is mentioned in paragraph (a), any such equipment as is mentioned in paragraph (b) or any such knowledge or information as is mentioned in paragraph (c);..."

Daar word aan die hand gedoen dat die aanvangsfranchisefooi as tantième behoort te kwalifiseer indien die doel van die fooi 'n betaling is vir die gebruik of reg van gebruik van die franchisegewer se handelsmerke, bedryfsgeheime, toerusting, tegniese kennis en of ondersteuning asook bystand wat met die gebruik van hierdie items gepaardgaan. Die aanvangsfranchisefooi kan moontlik as ' $n$ tantième ingevolge artikel 26-25 ITAA97 aftrekbaar wees.

Op die oomblik bevat die Suid-Afrikaanse Inkomstebelastingwet geen omskrywing van tantième of ' $n$ bepaling wat spesifiek voorsiening maak vir die aftrekking daarvan nie. Daar bestaan egter ook nie ' $n$ bepaling wat die aftrekking van ' $n$ tantième eksplisiet verbied nie.

Die aanlyn woordeboek, InvesterWords.com (2010) omskryf 'n tantième as: "a payment made for the use of property, especially a patent, copyrighted work, franchise, or natural resource. The amount is usually a percentage of revenues obtained through its use". Die begrip word ook as "compensation, consideration, or fee paid for a license or privilege to use an intellectual property (brand, copyright, patent, process) or a natural resource (fishing, hunting, mining,), computed usually as a percentage of revenue or profit realized from the use" (BusinessDictionary.com, 2010) omskryf

' $n$ Ontleding van die tantième-omskrywing toon dat daar ' $n$ fundamentele ooreenkoms tussen ' $n$ huurbetaling en ' $n$ tantièmebetaling bestaan. Beide hierdie betalings is vir die gebruik van een of ander tipe bate. Dit wil voorkom of tantièmebetalings, betalings is vir die gebruik of reg van gebruik van spesifiek intellektuele eiendom. 'n Betaling vir die gebruik of reg van gebruik van onroerende goed blyk egter nie tantième te wees nie, maar wel 'n gewone huurbetaling. Indien die aanvangsfranchisefooi dus vir die gebruik of reg van gebruik van intellektuele eiendom, toerusting, of kennis of meedeling van kennis met betrekking tot die gebruik van bogenoemde bates, betaal word, behoort die fooi aan die omskrywing van ' $n$ tantième te voldoen.

Sou die aanvangsfranchisefooi dus as ' $n$ tantième beskou kan word, sal dit in Suid-Afrika aan die hand van die algemene aftrekkingsformule beoordeel word. In die Appèlhofsaak BP Southern Africa (Pty) Ltd v CSARS [2007], 69 SATC 79 was die geskil voor die hof of die betaling van tantième op ' $n$ herhalende basis aftrekbaar is ingevolge die algemene aftrekkingsformule. Volgens die hof moet die ware aard van elke transaksie ondersoek word en elke geval sal op grond van sy eie feite en omstandighede beoordeel word. Voorts is die doe/van die onkoste belangrik en deurslaggewend. Die hof het die inkomstegenererende struktuurtoets gebruik en bevind dat die onkoste aangegaan is om die belastingpligtige se gebruik (nie eienaarskap nie) 
van die beheermaatskappy (aan wie die tantième jaarliks betaal is) se intellektuele eiendom te verkry vir die tydperk van die ooreenkoms en dat die ooreenkoms daarna beëindig kan word. In die hande van die belastingpligtige het die onkoste nóg enige kapitaalbates geskep, nóg dit in stand gehou. Vanweë die feit dat die betalings herhalend van aard was, was dit ' $n$ sterk aanduider dat dit ' $n$ inkomste van aard is. Die hof se siening was dat die onderhawige tantièmebetalings nie verskillend van huurgeld is nie, wat betaal is vir die gebruik van eiendom wat deur ' $n$ ander persoon besit word, met die gevolg dat die tantièmebetaling inkomste van aard was en dat dit dus van belasbare inkomste ingevolge artikel 11 (a) aftrekbaar was (Huxham \& Haupt, 2008:863). Die hantering van ' $n$ enkelbedragtantièmebetaling met dieselfde karaktereienskappe en doel as ' $n$ aanvangsfranchisefooi is egter nie deur die hof bespreek nie. Die hofsaak bevestig egter dat die aftrekbaarheid van enige tantièmebetaling aan die hand van die algemene aftrekkingsformule beoordeel moet word. ' $n$ Beoordeling van ' $n$ enkelbedragtantièmebetaling soortgelyk aan 'n aanvangsfranchisefooi behoort te toon dat dit kapitaal van aard is. Artikel 11 (f) kan egter nog oorweeg word waar die tantième betaal word vir die reg van gebruik van enige van die items van intellektuele eiendom wat in die artikel gelys is.

\section{FINALE GEVOLGTREKKING}

Die aanvangsfranchisefooi is nie ingevolge die algemene aftrekkingsformule aftrekbaar nie weens die feit dat die fooi as kapitaal van aard beskou sal word. Verder voldoen die fooi nie aan die vereistes van die Tiende Bylae of artikel $11(\mathrm{gC})$ nie, met die gevolg dat hierdie bepalings geen alternatiewe aftrekkings bied nie. Desondanks die feit dat die fooi as kapitaal van aard beskou word, het ' $n$ verdere ondersoek aan die lig gebring dat die fooi moontlik ingevolge artikel $11(f)$ aftrekbaar kan wees. Die doe/ waarmee die fooi aangegaan word en waarvoor die fooi aangegaan word sal van deurslaggewende belang wees ten einde te bepaal of die betaling van die fooi vir ' $n$ aftrekking ingevolge artikel 11 (f) sal kwalifiseer. Die aanvangsfranchisefooi moet dus duidelik uit die bewoording van die franchise-ooreenkoms tesame met die bedoeling van die franchisehouer en franchisegewer betaal word as teenprestasie vir die reg van gebruik (doel) van eiendom (waarvoor) van die franchisegewer. Die aftrekbaarheid van die fooi moet gevolglik op 'n saak-vir-saak-basis hanteer word en beoordeel word op grond van die spesifieke feitestel wat bestaan. Artikel 231 moet, waar van toepassing, oorweeg word.

Die fooi toon in sekere gevalle die eienskappe van ' $n$ tantième en kan as sodanig geklassifiseer word, maar hierdie feit verander egter nie, ingevolge huidige Suid-Afrikaanse inkomstebelastingwetgewing, die aftrekbaarheid van die fooi nie. In die afwesigheid van ' $n$ spesiale aftrekking wat spesifiek ' $n$ aftrekking vir ' $n$ tantième bied, sal die aftrekbaarheid van die fooi nog steeds aan die hand van die algemene aftrekkingsformule en artikel 11 (f) beoordeel word en die toetse wat daarvoor gebruik word van krag wees.

\section{AANBEVELINGS}

Die verwarring oor die omskrywing van 'n "premie of dergelike vergoeding" soos wat dit tans deur die Suid-Afrikaanse howe gebruik word, is in die artikel bespreek. Die paradoks kom voor waar ' $n$ premie omskryf word as 'n teenprestasie in die aard van huur wat benewens of in plaas van die huurbetalings van ' $n$ huurder na 'n verhuurder oorgaan. Die argument is dat ' $n$ premie nie terselfdertyd iets bo en behalwe huur kan wees asook iets in plaas van huur nie. Die omskrywing van ' $n$ premie is dus lomp en dubbelsinnig. Daar word gevolglik aan die hand gedoen dat ' $n$ 
behoorlike omskrywing van 'n premie as iets addisioneel tot huur ' $n$ bydrae daartoe sal lewer dat die premie as kapitaal van aard beskou word. Bogenoemde onderskeid stel die Wetgewer en die Fiskus in staat om die bepalings van paragraaf $(\mathrm{g})$ tot die bruto inkomste-omskrywing en artikel $11(f)$ doeltreffend te kan toepas. Die voorkoms van skyntransaksies behoort verminder te word, aangesien die "wese bo vorm"-beginsel meer effektief toegepas kan word om "versteekte" vooruitbetaalde huurbedrae te identifiseer.

Die artikel het aan die lig gebring dat die bewoording van ' $n$ franchise-ooreenkoms duidelik en ondubbelsinnig moet wees met betrekking tot die doel waarmee die onderskeie franchisefooie aangegaan word. ' $n$ Dubbelsinnige of swak gestruktureerde beskrywing van die aanvangsfranchisefooi kan daartoe lei dat dit nie aftrekbaar is nie. Waar die fooi vir meer as een doel aangegaan word, is dit van selfs groter belang om van duidelike, ondubbelsinnige bewoording gebruik te maak ten einde die aftrekbaarheid daarvan te bepaal. Effektiewe en gestruktureerde bewoording kan dus die franchisehouer help om vir 'n aftrekking ( $a$ lis dit slegs ' $n$ gedeelte) ten opsigte van die aanvangsfranchisefooi te kwalifiseer.

Die huidige Suid-Afrikaanse Inkomstebelastingwet bevat geen omskrywing van die begrip "tantième" nie. 'n Gedetailleerde omskrywing word dus aanbeveel. 'n Nuwe artikel in die SuidAfrikaanse Inkomstebelastingwet soortgelyk aan artikel 26-25 van die Australiese Inkomstebelastingwet behoort egter ' $n$ aftrekking te bied vir die aanvangsfooi waar die fooi aan die omskrywing van tantième voldoen. Die inkorporering van sodanige artikel sal egter ' $n$ Wetswysiging vereis. Sodanige artikel of bepaling behoort verwarring en oorweging van die aftrekbaarheid van die item aan die hand van die algemene aftrekkingsformule te beperk of te verhoed.

As alternatief behoort ' $n$ spesifieke aftrekking wat slegs van toepassing op franchisefooie is, oorweeg te word. Die artikel moet binne die korrekte konteks toegepas word. Hierdie artikel behoort voorts ' $n$ omskrywing van die verskillende franchisefooie te bevat ten einde onduidelikhede uit te skakel. Dit vergemaklik dus die beoordeling van die aftrekbaarheid van franchisefooie en skakel moeisame interpretasies uit. Hierdie aanbeveling verg dus ' $n$ wysiging van die bestaande Suid-Afrikaanse Inkomstebelastingwet. Die toevoeging van nuwe artikels tot die Inkomstebelastingwet kan egter voorkom word deur slegs artikel $1 \mathrm{l}(\mathrm{f})$ en paragraaf $(\mathrm{g})$ van die woordomskrywing van bruto inkomste te wysig om spesifiek ' $n$ aanvangsfranchisefooi in te sluit. ' $n$ Bepaling soortgelyk aan artikel 40 - 880 ITAA97 ten opsigte van "blackhole"kapitaalonkoste binne ' $n$ Suid-Afrikaanse konteks behoort ' $n$ bykomende opsie aan ' $n$ franchisehouer te bied om die fooi af te trek, aangesien dit eintlik aangegaan word om die franchisebesigheid te vestig of te skep. 'n Toepaslike aangepasde weergawe van artikel $40-880$ ITAA97 binne die Suid-Afrikaanse Inkomstebelastingwet word dus a anbeveel.

Ten slotte word aan die hand gedoen dat hierdie artikel beginsels uitgelig het wat die verwarring rakende die inkomstebelastinghantering van franchisefooie uit die oogpunt van die franchisehouer, moontlik kan opklaar. Hierdie inligting kan dus as 'n nuttige hulpmiddel dien vir rolspelers in die Suid-Afrikaanse belastingomgewing wanneer bostaande aangeleentheid na vore tree.

\section{BRONNELYS}

Angelopulo, B.D. (2005). Franchising [Intyds]. Beskikbaar: http://www.lib.sun.ac.za.ez.sun.ac.za/ nxt/gateway.dll?f=templates $\$ f n=d e f a u l t . h t m \$ v i d=m y l n b: 10.1048 /$ enu. [27 Oktober 2009]. 
Blair, R.D. \& Lafontaine, F. (2005). The economics of franchising. New York: Cambridge University Press.

Borstlap v Sekretaris van Binnelandse Inkomste [1981], 43 SATC 195, (4) SA 836 (A).

Botha, C. (1998). Wetsuitleg - ' $n$ Inleiding vir Studente. Kaapstad: Juta \& Co, Ltd.

BP Southern Africa (Pty) Ltd v C: SARS [2007], 69 SATC 79.

Brownlie, S.P. \& Jooste, R.D. (1995). The Lease Premium Concept in South African Tax Law. Acta Juridica, 1995, pp. 241-256.

BusinessDictionary.com. (2010). [Intyds]. Beskikbaar:

http://www.businessdictionary.com/definition /license.html. [19 Oktober 2010].

Case C271 ATC 8.

CIR v Butcher Bros (Pty) Ltd [1945], 13 SATC 21, AD 301.

CIR v Manganese Metal Co (Pty) Ltd [1996] 58 SATC 1, (3) SA 591.

CIR v Nemojim (Pty) Ltd [1983], 45 SATC 241, (4) SA 935 (A).

Clegg, D. \& Stretch, R. (2008). The general deduction formula. Income Tax in South Africa [Intyds]. Beskikbaar: http://www.lib.sun.ac.za.ez.sun.ac.za/nxt/gateway.dll/7b/6d/mkfa/xImk. [23 Junie 2010].

De Koker, A.P. (2008). Judicial decisions. Silke on South African Income Tax [Intyds]. Beskikbaar: http://www.lib.sun.ac.za.ez.sun.ac.za/nxt/gateway.dll/7b/ae/zaa/0eok. [23 Junie 2010].

FC of T v. Krakos Investments Pty Ltd 96 ATC 4063.

Franchise fees. [S.a.] [Intyds] Beskikbaar: http://www.whichfranchise.co.za/article.cfm?Article ID=27. [5 Mei 2009].

Huxham, K. \& Haupt, P. (2008). Aantekeninge oor Suid-Afrikaanse Inkomstebelasting. Roggebaai: Hedron Tax Consulting and Publishing CC.

Huxham, K. \& Haupt, P. (2010). Aantekeninge oor Suid-Afrikaanse Inkomstebelasting. Roggebaai: Hedron Tax Consulting and Publishing CC.

Illetschko, K. \& Parker, દ. (2007). Franchising in South Africa: The real story. Paarl: Paarl Print Income Tax Assessment Act 1936 Act No. 27 of 1936 of Australia as amended.

Income Tax Assessment Act 1997 Act No. 38 of 1997 of Australia as amended.

InvestorWords.com. (2010). [Intyds]. Beskikbaar: http://www.investorwords.com/2798/license.html. [19 Oktober 2010].

ITC 3539 SATC 82.

ITC 61314 SATC 389.

ITC 72818 SATC 94.

ITC 1764 66 SATC 83.

Levy v Commissioner for Inland Revenue [1930], 5 SATC 119, NLR.

Mincer Motors Ltd v Commissioner of Customs and Excise [1958], (1) SA 652 (T).

New State Areas Ltd v CIR [1946], 14 SATC 155, AD 610. 
Nixon v. Doney (1960) NSWR 2.

OECD Member Countries. [S.a.] [Intyds]. Beskikbaar: http://www.oecd.org/countrieslist /0,3351 en_33873108_33844430_1_1_l_1_l,00.html. [11 November 2010].

Republiek van Suid-Afrika. (1962). Inkomstebelastingwet, nr. 58 van 1962. Pretoria: Staatsdrukkery. Republiek van Suid-Afrika. (1977). Wet op Petroleumprodukte, nr. 120 van 1977. Pretoria: Staatsdrukkery.

Secretary of Inland Revenue v Guardian Assurance Holdings (SA) Ltd [1976], 38 SATC 111, (4) SA 522 (A)

Stiglingh, M., Koekemoer, A.D., Van Schalkwyk, L., Wilcocks, J.S., De Swardt, R.D. \& Jordaan, K. (2010). SILKE: Suid-Afrikaanse Inkomstebelasting 2010. Durban: LexisNexis.

Taljaard, J.C. (2001). Geld die gewone reëls en beginsels van wetsuitleg by die uitleg van belastingwetgewing? Stellenbosch: US Drukkery.

Turnbull v CIR [1953], 18 SATC 336, (2) SA 573 (A)

Van Schalkwyk, L. (2010). Uitleg van Belastingwetgewing 5. Ongepubliseerde klasnotas (MRek (Belasting) / MComm (Belasting)). Stellenbosch: Universiteit van Stellenbosch.

Verklarende Handwoordeboek van die Afrikaanse Taal. 1994. Doornfontein: Perskor

Woellner, R., Barkoczy, S., Murphy, S. \& Evans, C. (2003). Australian Taxation Law 2004, Fourteenth Edition, CCH Australia Limited, Sydney. 
INKOMSTEBELASTINGHANTERING VAN AANVANGSFRANCHISEFOOIE IN DIE SA PETROLEUMBEDRYF 